\title{
Media Reconciliation of Values with Votes in the 2016 US Presidential Election
}

\author{
Dr. Ayo Elebute ${ }^{1}$, Josephine Omoruyi ${ }^{2}$ \\ Department of Mass Communication Igbinedion University, Okada, \\ Department of Mass Communication \\ Igbinedion University, Okada
}

\begin{abstract}
This piece is an attempt at studying the trajectory of media reportage of 2016 presidential election in the United States, presenting the myriads of methods used by the media practitioners to reconcile the values of the two presidential candidates with the votes of the electorate. The issues relating to symbiotic relationship of values and indecent languages that characterized the United States' presidential debates and campaign rallies were expatiated in detail. Some attention is paid to types of agenda setting and the complex trending relationships that scholars have observed on issues relating to values and votes covered by the social media and traditional media. It is shown that both presidential candidates in the 2016 US election have a significant increase in the media coverage. An attempt is made at examining the reasons for the erroneous assumption from certain quarters that Donald Trump would probably never make it past $20 \%$ electoral support. The final results showed an overwhelming majority of mentions to Trump and despite external factors that might have affected the range of media coverage given to each candidate, it is clear that the media dominated their reportage with a focus on Trump's moral flaws and still he won the presidential race.
\end{abstract}

Key words: Media reportage, Presidential election, Values and indecent languages, Presidential candidates, Presidential debates

\section{INTRODUCTION}

Values and votes will definitely be recorded as interdependent variables in the epic of recent 2016 United States' election, because during electioneering rallies and campaigns, as was observed by Benson (2016), "values and decency yielded way to the profanity" and crude Rhetorics were used to "persuade eligible voters to vote for presumptive candidates". Warp and raw system of communication is considered the most pervasive influence of voting patterns of the electorate and also, the very origin of hate speeches. The symbiotic relationship of values and indecent languages that characterized the US presidential debates and campaign rallies is said to have created a 'war complex' in which candidates' speeches went from the sublime to the ridiculous. Sometimes, the political messages of Trump and Clinton: the two main presidential candidates in the 2016 US elections rang hallow, lacking substance and focus. Sadly, the frequency of negative sound grips that erupted from some of their rallies, as recorded by the media worldwide, obviously generated a large number of sceptical voters.

The role of mass media in this United States' political lockjaw can be deciphered within the context of myriads of theoretical frameworks that explain the significance of the media profession in governance. These frameworks are helpful in extrapolating the general trend of media activities in this United States' electioneering process of 2016 from a public sphere perspective. In Isola's (2010: 9) summation "the media is a public sphere that provides a space that mediates between civil society and the realm of power". This angle to media activities in the political life of electorate has been further articulated by Habermas (1989:49) in his earlier theses that defined the public sphere as: organs of information and political debate such as newspapers, journals as well as institutions of political discussion such as parliament, political clubs, literary salons, public assemblies, pubs, coffee houses, meeting halls and other public spaces where socio-political discussion took place

Observably, the social media have successfully moulded the public's conversation, during the 2016 US election, by attributing importance to some issues over others. In this US political logjam the social media were used to sharpen the public's conversation by attributing more twitter mentions to a specific candidate and, in turn, exposing the electorate to a candidate more than the others. It is revealed that the more the media tweeted about a certain candidate, the more they influenced voters and this was how the majority of the delegates accounted for on three Super Tuesday primary elections were solicited and procured. The above revelation in media tweeting is in consonance with Emett (1966:33) views that: the media in general exert a 
steady pressure on the 'electorate' that it is hardly doubted that they constantly modify voters' behaviour, alter their attitudes and opinions, extend the range of

their cultural experiences, increase their stock of information and even affect such voters' individual characteristics or their initiatives and ambitions. In a related allusion to Emett's conception of media pressure on voters' behavioural attitudes and voting patterns, Popoola (2015:21) avers that "any change in human society, real or imaginary, could be traced to the baleful influence of one or other mass media". Using the dominant effects of Hypodermic Needle Theory as a yardstick to support this omnipotent and very powerful media paradigm he noted that "the media have direct and immediate effects on their audience".

At this juncture it is apposite to state that the traditional role of mass media is to educate, inform and entertain the audience until the introduction of other numerous functions by Harrold Lasswell, which were identified by Ate (2008) as surveillance, transmission of cultural heritage, status conferral, interpretation and prescription of news, and agenda setting. Noticeably, the media in performing these functions have been able to: 1) educate the US electorate with a view to broaden their horizon through different programmes that have developed them mentally and morally 2 ) inform the US electorate by creating political awareness that can afford them to know what is happening and what has happened in the US political terrain 3) entertain the US electorate by making them to laugh and forget their sorrows 4) provide information to the US electorate by keeping watch on the activities of political candidates and correcting uncomplimentary occurrences during political rallies 5) transmit knowledge, values and social norms to the US electorate, and making them to share common values and to agree on what constitute acceptable behaviour in electoral process 6) confer status on the two presidential candidates: Clinton and Trump by making them subjects of news reports 7) select, evaluate and interpret the US political news items by focusing on what is most significant in the milieu in order to prevent over stimulation and over mobilization of the population and 8) lead the voting public in taking very sensitive decisions on issues of public importance and influencing the thinking of the voting public through its court of public opinion.

The primary objective of this study is to assess the level at which values are being harmonized with votes in the 2016 US electoral processes using the mass media as a tool of reconciliation. This is not a particularly difficult discourse, considering the current level of human political knowledge, but given its universal character, it could be considered as being significantly volatile, if not utterly explosive, within the context of the global politics. Significantly, therefore, the organizing of formal conversation on the general theme: Donald Trump's Presidency in America: What implications for Nigeria and Africa, is but a manifestation of the importance and relevance of this researcher's subject: Media Reconciliation of Values with Votes in 2016 US Election, especially as it concerns the question of understanding political culture of North America for the purpose of human advancement, peace and international security. The secondary objectives of the study are to: (1) determine the values that shape the candidates held priorities (2) analyze how candidates' platforms relate to values and key policy issues and (3) assess the significance of the current election and the potential long-term impacts of its outcome.

\section{REVIEW OF RELATED LITERATURE}

It is worthy of mention that many scholars have researched into the issue of media coverage of elections as it pertains to traditional media organizations. Also, there is a growing field research exploring the effects of social media within the context of world elections. Some local and foreign scholars who have been identified as aces in this area of academic pursuit include: Geer (2015), Adeosun (2016), Akerele-Ogunsiji (2016), Aziken (2016), Aziken and Oke (2016), Barbour (2016), Benson (2016), Beutler (2016), Cruz (2016), Igiebor (2016), Kluver, Hinck and Cooley (2016), Knigge (2016), Ohai (2016), Osifo-Whiskey (2016), Plouffe (2016), Rasmussen (2016), Scott (2016) and Sobechi (2016).

Geer does a research to look into gatekeeping and agenda-setting in the 2016 US presidential election, and discovers that "the involvement of social media strategy has progressed immensely, changing the landscape of influence for both candidates and constituents". Adeosun sees the election of Trump over Clinton: the 'preferred' candidate, despite his hate campaign against a section of the American populace and his dismissal of the country's foreign policy initiatives as "a unique American way of taking care of her interest irrespective of the feelings of other people".

Akerele-Ogunsiji headlines his newspaper article: Hillary Clinton's Life gives Hope to Girls with Leadership Skills. He titles this article with the intention of highlighting and emphasizing the fact that "Hillary Clinton's statecraft has triggered and elevated the aspiration of an entire generation of women from all corners of the globe" In his opinion, "Clinton's statecraft is the hallmark of a leadership". Aziken and Oke write on how American-Nigerians are making historic move to stop Donald Trump's presidency ambition by way of using the 2016 presidential election to reverse the negative narrative and bias against Nigerians by the mainstream political class in the United States. Barbour evaluates the value of 2016 US elections' presidential debates and concludes that "unlike traditional challengers of who little is known before the campaign, Trump himself has been in the public eye for just as long as Clinton... he has also garnered an unprecedented amount of media 
attention throughout the campaign, suggesting that despite all hype, there is little new face-off can reveal about either candidate". Benson considers the effect of Halloween Day celebration of October 312016 on voting patterns of the Americans and identifies the fact that a sharp political divide was subsumed in the festivities of the cold eve. He avers that "the twisted celebration was not strong enough to unite Americans momentarily as a divided people cast their ballots to elect the next president in November 82016 barely a week after the Halloween Day celebration".

Beutler interrogates the reasons why the media is botching the election and alleges that "the falsebalance coverage of Hillary Clinton and Donald Trump is all about the press's self interest". While addressing the usual throng of press reporters Cruz states that "the mainstream media loves talking about Donald Trump". This statement was relayed by the media, complete with a loud reference to Trump in the news headline with a confirmation that for several weeks countless articles have wondered aloud whether too many articles are being written about Donald Trump. Then a question may be asked: Is the media to blame for Donald Trump frequent appearance in the media? To the researcher of this present study there are several strong reasons to take on the question, and several strong reasons to raise doubt about the conclusion.

Igiebor does a countdown to Trump's presidency and feels that "the world can only live on a wing and a prayer that, the Donald's eventual collision with the reality of the inexorable waning of Pax-Americana would terminate his crazy idea of triggering a new era of American isolationism". Kluver, Hinck and Cooley converse on how media outlets from around the world are reacting to the presidential campaign in the US. They focus on Chinese media, Russian media, and the Arab media outlets and conclude that "though these news outlets and their readers are not voting, but the views of the foreign press matter...they influence the new administration's ability to develop and promote a foreign agenda, they can also undermine how America is perceived in the areas that its leaders say matter the most: fairness, rule of law and human rights".

Knigge conducts an interview with Philip Klinkner, a professor of government at Hamilton College in the US and deduces from the interview that "Trump's election is evidence of the retrenchment of liberal values... his victory is a sign that the US is entering a period of the retrenchment of egalitarian ideals". Ohai opines that "a significant number of the American population will not be allowed to participate in the 2016 election because the law has stripped about six million Americans convicted of various offences of ther voting rights". Osifo-Whiskey compeers the Nigeria, Donald Buhari and Muhammadu Trump and concludes that: this American great (Trump) may well be trending not so much because of his humongous wealth, but for his limitless amazing personality, his prodigious sense of judgement and his wonderful capacity with great intuition and exactitude to creatively polarise society to achieve a superlative grade of political result.

Plouffe, in an interview on NBC's “Meet the Press" labels Trump a 'psychopath' who needs clinical attention. Rasmussen's reports on voters' views claim that "media, not candidates, are setting agenda for 2016 presidential election in the US". Scott assumes that "negative views of Donald Trump has just hit a new campaign high: 7in 10 Americans". Sobechi subjects American democracy to trial when he says that "if the Republican candidate Trump, carries the day, the implications for the world would be far-reaching...it would mean a return to individualism and good bye to America as the capital of the world and the land of opportunities".

In addition to these myriads of research works other related articles have appeared in academic journals and most scholars who pursued research in this area of human endeavour have divergent views. They perceived the media content and subjects on presidential campaigns and elections from different windows; each groping for answer to the erring challenges in the path to this area of human knowledge differently. Most of them are not focusing on the subject of this present study, the lack of concentration on it has created a yearning gap in knowledge and this is what this research intention is trying to fill. Moreover, this present study is not designed to follow the parts that the aforesaid scholars had taken verbatim, but valuable information accrued from what they have in their literature will be adopted to articulate the foundational elements of this present academic discourse.

\section{THEORETICAL FRAMEWORK}

In order to explain or interpret the phenomenon surrounding the 2016 US presidential election and to arrive at solutions to intellectual challenges that it poses Agenda Setting Theory will be used. The theory will serve as an ideational structure on which our arguments will be based. The main thrust of the theory is that while the mass media may not be powerful enough to determine for audience what and how to think they are influential in determining what the audience think about at a particular time, that is, they predetermine what issues are regarded as significant at a given time in a given society. Precisely, the mass media set agenda for the electorate during political campaigns; they keep political discourse alive and they help to bring some people to public prominence, fame or notoriety. Folarin (2006) identifies four major instruments that can be used to prosecute this aspect of agenda setting, they are: (1) the quality or frequency of reporting an issue (2) prominence given to the reports through headline display, pictures and layout in newspapers, magazines, films, 
graphics or timing on radio and television (3) the degree of conflict generated in media reports and (4) cumulative media specific effects over time. Lang and Lang (1983) have, however, drawn attention to two significant factors in agenda setting, these are: (1) the reciprocal effect concerned with the very presence of the media at the scene of an event and (2) the landslide effect that refers to the exaggerated impressions created by the type of media reporting audiences' reactions to a given issue. Kunczik (1998), in his own case, signifies the procedures that are apropos for examining agenda setting and one of his significations point to comparisons between media content over a certain period of time and the subjects that most people in the society are discussing. McQuail (1987) sums up the argument on agenda setting theory of the media when he concludes that "the press can colour events by using them in a particular way or refusing to use them at all". It is apposite to say that the above agenda setting theoretical postulations are germane to the 2016 US presidential election in which media organizations made decisions about stories to be printed or to go on air and how much coverage should be given to each. When the media printed and/or aired these electoral stories the public gathered the information, created an opinion and generated reaction on the activities of the two presidential candidates: Clinton and Trump, which the media had covered. Suffice to state that the 'uncivilized' campaign approaches adopted by the two presidential candidates generated more interesting discussion among the public and by default became the public agenda. Obviously, the media did not succeed at telling the public how to think in this direction, but it succeeded on telling them what to think about. It can therefore be argued that the media did shape what the public think is relevant by simply sifting informational issues arising from the political rallies organized in the American cities.

The above argument is in consonance with the general belief that there might be a hidden agenda behind power relations that influenced media coverage of the election. Some political thinkers have termed this as power relations between media and other sources, and Littlejohn and Foss (2010) have classified this political relativism into four: (1) high-power source and high-power media (2) high-power source and lowpower media (3) low-power source and high-power media and (4) low-power source and low-power media. Agenda setting theory, as is observed by McCombs (2006), "has become a highly detailed map of the mass media and its effects". Dearing and Rogers (1996) have expatiated on its three key components which are: (1) media agenda: that focuses on importance of issues to be discussed in the media (2) public agenda: that focuses on issues of discourse that have impact over what public think is important and (3) policy agenda: that is influenced by the public agenda.

The existence of agenda setting theory has greatly been fortified by the emergence of the Internet and social media and this has considerably weakened the power of traditional media and their pristine primordial hegemonic and monopolistic tendencies over news coverage. This hegemonic breakdown was well pronounced during the 2016 US presidential election in which individual had the privilege of posting, sharing, and republishing content to the web through easy-to-use web (2.0) publishing tools. This responsiveness of web 2.0, according to Meraz (2011) has "facilitated an enhanced degree of connectivity, collaboration, and conversation among decentralized web publics”.

\section{RESEARCH QUESTION AND HYPOTHESIS}

RQ: Do media have the ability to reconcile the candidates'values with peoples' votes in the 2016 US presidential election? The impact of media on the US political landscape is becoming a significant matter in the study of the 2016 political campaigns. Media experts have made frantic efforts to underscore the effects of media on many types of agenda setting and a growing line of academic research is on-going to examine the complex trending relationships that were observed on issues relating to values and votes covered by the social media and traditional media. In factual sense, myriads of media: traditional and social were widely adopted to facilitate constituent dialogue and to create news on candidates' values and the voting patterns of the electorate. HI: Media will have the ability of influence to reconcile the candidates' values with peoples' votes in the 2016 US presidential election. This assumption is based on the second-level of agenda setting that examines the transposition of salience of issues on news media agenda to the public agenda. The assumption is that a persuasive presidential candidate will, through the use of mass media, bend the will of the electorate to his side. This assumptive example will be hung in the ability and ingenuity of candidates to change voters' negative views about their political inclinations and policies. In such hypothetical instance the ultimate goal of the candidates will be geared towards influencing voters' electoral behaviour via the media so that they will be voted for. The veracity of this hypothesis depends on the success of media prominence of mentions about a particular presidential candidate and whether or not they effectively and effectually change the attitudinal behaviour of the voters during political rallies.

\section{METHODOLOGY}

Data for the study were collected through two major sources: primary and secondary. As the presidential contest in the US engaged the interest of many Nigerians the primary data were gathered through in- 
depth interviews and observational method in which the researcher observed Nigerians reactions to media messages on 2016 US presidential elections and how their actions upon the messages were modified by their informal social relationships with friends, relations and social groups internally and across borders. This researcher personally handled the task of asking some of these interested respondents residing in Nigeria to consider what values and skills they consider necessary for the US presidential candidates. A question was asked to know if there are specific viewpoints or policies that these respondents would want the candidates to prioritize and they were equally asked to distinguish the two main candidates of the 2016 presidential election from each other. In particular, it was discovered that decisions of American voters were somehow determined by public discussions generated by peoples across the globe and by media campaigns in general. The secondary data were collected through journals, books, newspapers, magazines and the Internet. The researcher made a systematic classification and description of the communication content according to predetermined categories and as well made replicable and valid inferences to the message content of the secondary data to their context. The overall data were at first subjected to scrutiny in order to ascertain their veracity. After ascertaining the data to be genuine, they were then synthesized and interpreted.

\section{DATA ANALYSIS}

The study has been able to establish the fact that both presidential candidates in the 2016 US election have a significant increase in the media coverage. The media show the innate ability to effect cognitive change among eligible voters and to structure their thinking with stunningly success in telling them what to think about the candidates. In consonance with McCombs and Shaw (1972) theoretical postulations that "the more coverage an issue receives, the more important it is to people", it can be reiterated that the global media coverage of the US political events has displayed a high level of professionalism, most especially in the process of presenting certain issues of global concern frequently and prominently with the result that large segment of the American public began to see those issues as more significant than others.

For example, among the global media coverage via 60 different news outlets in regions that represent over 1.5 million, the Chinese media consistently focused on both candidates' weaknesses like Clinton's email controversy and Trump's sexual harassment issues, but they still gave ample attention to the candidates' policies on trade. The Russian media criticized the electoral debates for the way the candidates have spent most of the time talking about negative qualities of their opponents' failure and not presenting their vision for the development of the economy. The Arab media frequently praised Clinton's position that the Muslims are part of America's dream, but cast Trump's anti-immigrant views negatively and qualified his candidacy as a 'sad scenario' in Western democracy.

The election has provided evidence that media assumptions about voters are wrong. It is this assumption that readily relayed the importance in comprehending the real connection between the media and Trump's ascension to presidency. For instance, Trump's right-wing populist supporters strongly felt ignored and frustrated in the beginning by the mainstream media establishment and no one was apprehensive of how this initial media coverage that ridiculed them might have garnered the greater support of white voters. Retrospectively, their frustrations have helped in electing Trump who addressed their economic and cultural fears in his manifestoes. It is apposite to state clearly that the recorded end success of Trump negates the erroneous assumption that he would probably never make it past $20 \%$ support while hypothesising that he is a one social occurrence whose supporters were simply misguided in their choice for the next American president. The media assumptions as were observed by this researcher have significantly accounted for the candidates' strategy of using social media to change the landscape of influence for themselves and their constituents, and to connect with their supporters at a more personal level. In this instance, the candidates had the privilege to act as gatekeepers by pushing information that fits their political platform and image for the audience to interpret the content therein as more salient based on preconceptions of the source it is coming from.

Above all else, feelings of frustration, disgust and fear arose among voters in the US penultimate elections as myriads of Clinton and Trump supporters declared that their presidential choice was driven by a dislike of the other candidate. A research survey released by Pew Research Centre in the US revealed that 57 percent of eligible voters who responded to these sentiments felt frustrated; 55 percent felt disgusted; 43 percent of the respondents were scared; 31 percent of the respondents were less interested; 15 percent optimistic and 10 percent excited. Similarly, Trump and Clinton supporters expressed these levels of frustration: 55 percent and 53 percent respectively, and differed a little in their feelings of disgust: 53 percent and 48 percent. The poll documentation recorded by Pew Research Centre also revealed the fact that 33 percent of Trump supporters in Republican Party supported him because "he is not Clinton", while 32 percent of Democratic Clinton supporters supported her because "she is not Trump".

However, three major factors used through the media to estimate the leadership worth of Hilary Clinton before the electorate have served as instruments to Trump's success at the poll. The first is the theme of his campaign strategy that reads: Make America Great Again, which resonated with "millions of White voters who 
felt alienated by the force of globalization and multiculturalism" (Adeosun, 2016:13). Records show that 70 percent of these Whiter voters without college education accounted for his ascension to the political throne while 59 percent of them with degree also cast their votes for him accordingly. The second factor was the email saga against Hilary Clinton, and the last minute move by the Federal Bureau of Investigation (FBI) to revisit the case. This e-mail scandal had dogged Clinton throughout the campaigns and was used by the Republicans and Trump in attacking her personality and character as well as projecting her as dishonest and unworthy of the public trust. Although the issue was put to rest for a while, but the FBI director brought it up eleven days to the final election and this reinvestigation dealt a final blow on her presidential ticket bid, despite the last minute clearance.

The third factor is premised on the belief that Trump's stance against abortion and gay marriage, which Clinton promised to uphold may equally have earned him more support from the traditional conservative Americans who constitute part of the native Americans. Noticeably, the support for Clinton is not universal especially given her very liberal social stance which is at variance with the conservative cultural leanings of many people in the world who are appalled with her strong support for homosexual rights among other social inclinations that are held at bay by humans. The success of Trump has, however, been viewed in many quarters as a stunning upset that proved the polls, the pundits, and the data wrong. This success ridicules a massive failure of the prognosticating machine, which forecasted that the better financially backed, well linked, limitlessly more accomplished Hillary Clinton; the candidate of the Democrats would create the record of becoming the first woman US president. Trump won the race with approximated 59,229,386 popular votes and 289 electoral votes, in contrast to $59,413,982$ popular votes and 218 electoral votes for Clinton.

\section{CONCLUSION}

The US presidential election has been voted as the longest, most expensive and arguably most watched election on the entire planet. The most difficult aspect of this election exercise to comprehend is the avalanche of predictions stating that particular candidate is ahead, behind or likely to win. Suffice to cite some of these predictive estimations, which showed that Trump's unfavourable rating far eclipsed Hillary Clinton's even as the assumptive Democratic candidate got her unfavourable ratings in more than two decades in her public life. Clinton's bumper prominence endeavour continued to be among men, where her unfavourable rating stood at 63 percent, rising to 75 percent among white men. Her standing with women is significantly better at 51 percent favourable and 47 percent unfavourable.

One fact remains that the 2016 presidential election in the US is a political effort to witness barbarous campaigns in the annals of America's 240-year. The campaigns went from the lofty to the preposterous. A good instance of people going to absurd length in political rhetoric is derivable from the action of former Obama's aide Plouffe's (2016) who in an interview on NBC's programme "Meet the Press" labels Trump a 'psychopath' that meets the clinical definition of the personality disorder. Another example surfaced when Trump threatened to clamp his opponent Hillary Clinton in jail whenever he assumes the reins of power. Given these crude Rhetorics, the victor of this ugly election may not emerge wholly unharmed as the country's 'brand' may have been irreparably injured with its good standing in the world polity being lost.

The conclusions of this study indicate that the mass media exercised a significant function on what voters considered major issues or most important issues in the 2016 US presidential election. This influence is mainly due to the devoted portion of coverage given to certain issues on the two presidential candidates by the mass media. The study utilized two major sources of data collection: primary and secondary. As the contest engaged the interest of many Nigerians the primary data were gathered through in-depth interviews and observational method in which the researcher observed Nigerians reactions to media messages on US presidential elections 2016 and how their actions upon the messages were modified by their informal social relationships with friends, relations and social groups internally and across borders. The secondary data were gathered through analysis of the message content in books, journals, newspapers, magazines and the Internet. The data were scrutinized, verified and modified before being analyzed. The results indicated that there are overwhelming majority of mentions to Trump and despite external factors that might have affected the range of media coverage given to each candidate, it is clear that the media dominated their reportage with a focus on Trump's moral flaws and still he won the presidential race. Assuming that the media transferred the prominence of Trump to potential voters, the overall results still presented some inconsistencies as it is related to Hillary Clinton's position.

\section{IMPLICATIONS OF TRUMP'S VICTORY FOR THE US, NIGERIA AND AFRICA}

If we are to follow the words of Knigge (2016) this scenario of Trump's Victory will be rightly viewed as a sign that the US is entering an era of the retrenchment of egalitarian ideals, which is a belief in human 
equality especially in social, political and economic affairs. Noticeably, a visible trend in which eras of egalitarian gains are followed by long periods of retrenchment is deeply rooted in American history. The reason for this, according to Knigge, is not far-fetched: America is not uniquely committed to egalitarian ideals, but she has always been having a battle between democracy, liberty, equality and ideas that run against a belief in hierarchies defined by gender, race or religion... and every period of advancement in the United States has been followed by these periods of retrenchment" (Knigge, 2016:1). As most people of the world are apprehensive of the aftermath of his emergence as POTUS (President Of The United States) some African leaders are having the feeling that "it would be difficult to predict his policies toward Nigerians or Africans in the Diaspora and the continent itself" (Akinyemi, 2016:12). Although, he promised in his victory speech to deal fairly with other nations when he reiterated that: "I want to tell the world community that while we will always put America's interests first, we will deal fairly with everyone...All people and all other nations... we will seek common ground, not hostility; partnership, not conflict", but considering his political rhetoric and the kind of character he vented during his rallies, many are still in fear, uncertain what his dispositions will be in power. It is also a belief in some district that his assumption of office will prompt Africans and other developing nations to be more inwardly serious and committed to the desired development of their respective societies. Gambari (2016:13) has in this vein advised the leadership of Nigeria and Africa "to promote policies in the interest of the citizens as such interests would encourage development and reduce the flow of African citizens to western countries".

\section{REFERENCES}

[1] Adeosun,O. (2016) America's Trump card Tell Magazine November 21 pp10

[2] Akerele-Ogunsiji, T. (2016) Quoting Calvin Coolidge in an interview on Hilary Clinton's life gives hope to girls with leadership skills The Guardian November 8 pp15

[3] Akinyemi, B.(2016) Describing Trump's victory as a worrisome development An interview in Tell Magazine November 21 pp12

[4] Ate, A.A. (2008) Media and Society Lagos: NOUN Course Material JLS713Aziken, E. (2016) Electoral College: America's secret way of electing President Vanguard Newspaper November 8 pp44

[5] Aziken, E. and Oke, G. (2016) American-Nigerians in historic moves to stop Trump Vanguard Newspaper November 8 pp44

[6] Barbour, R. (2016) US elections 2016: Debating the value of Presidential Debates Interview New York: Hofstra University in Hempstead September 26

[7] Benson, D. (2016) Reconciling values with votes Vanguard Newspaper November 8 pp45

[8] Beutler, B. (2016) Why the media is botching the election-The "false balance" coverage of Hilary Clinton and Donald Trump is all about the press's self interest New York Times September 23

[9] Cruz, T. (2016) Fact-check: Is the media really to blame for Donald Trump? An Address to a throng of press reporters published in Washington Post Retrieved from the Net

[10] Dearing, J.W. and Rogers, E.M. (1996) Agenda-setting Volume 6 Thousand Oaks CA: Sage

[11] Emett, B.F. (1966) The design of investigation into the effects of Radio and Television programmes and other Mass Communications Journal of Royal Statistical Society, xii

[12] Folarin, B. (2006) Theories of Mass Communication: An introductory text Ibadan: Stirling-Hordens Publishers

[13] Gambari, I. (2016) Optimistic the US laws and institutions would protect Africans, An Interview in Tell Magazine November 21 pp13

[14] Geer, S. (2015) Gatekeeping and agenda-setting in the 2016 Presidential Election Posted in Facebook with \#Feel the Bern

[15] Habermas, J. (1989) The structural transformation of the public sphere Cambridge: Polity

[16] Igiebor, N. (2016) America and the rest of us Tell Magazine November 21 pp3

[17] Isola, O.O. (2010) Mass Media and Election Violence 1965 and 1983 Experiences in Western Nigeria Ibadan: John Archers

[18] Kluver, R; Hinck, R and Cooley, S (2016) How media outlets from around the world are reacting to the Presidential campaign Conversation funded by Barclays Africa and Nine Universities Texas: Texas A\&M University

[19] Knigge, M. (2016) Trump's election is evidence of the retrenchment of liberal values An Interview with Phillip Klinkner of Hamilton College Retrieved from the Net

[20] Kunczik, M. (1998) Concepts of Journalism: North and South Bonn: Friedrick Eberst Stiftung

[21] Lang, K. and Lang, G.(1983) The battle for public opinion: The President, the Press and the polls during Watergate New York: Columbia University Press 
[22] Littlejohn, S.W. and Foss, K.A. (2010) Theories of Human Communication( $10^{\text {th }}$ edition) Long Grove IL: Waveland Press Inc;

[23] Meraz, S. (2011) Using time series analysis to measure inter-media Agenda-setting influence in traditional media and political blog networks Journalisms and Mass Communication Quarterly 88 (1) 176-194

[24] McCombs, M. (2006) Setting the Agenda: The Mass Media and Public Opinion Cambridge: Polity

[25] McCombs, M.E. and Shaw, D.L. (1972) The Agenda-setting function of Mass Media The Opinion Quarterly 36 (2) 176-187

[26] McQuail D. (1987) Mass Communication Theory: An Introduction London: Cassell and Collier

[27] Ohai, C. (2016) World watches as US elects new president today Punch Newspaper November 8 pp12

[28] Osifo-Whiskey, O. (2016) Nigeria, Donald Buhari and Muhammadu Trump Tell Magazine November 21 pp5

[29] Plouffe, D. (2016) Former Obama aide calls Trump a psychopath an interview recorded in Vanguard Newspaper August 29 pp41

[30] Popoola, M. (2015) A Discourse on Personality-induced conflicts in Nigeria's Politics-The Media and their Narratives Ibadan: John Archers

[31] Rasmussen reports (2016) Voters say media, not candidates, setting agenda for2016 election Pulse Opinion Research LLC Tuesday August 30

[32] Scott, C. (2016) Negative views of Donald Trump just hit a new campaign high:7 in 10 Americans Washington Post-ABC news Polls June 15

[33] Sobechi, L. (2016) As democracy goes on trial in the United States The Guardian November 8 pp14 